\title{
Phosphoproteomic Analysis of AML14.3D10 Cell Line as a Model System of Eosinophilia
}

\author{
Su In Ryu ${ }^{1,}$, Won Kon Kim ${ }^{1, \#}$, Hyun Ju Cho ${ }^{1}$, Phil Young Lee', Hyeyun Jung', Tae-Sung Yoon ${ }^{2}$, \\ Jeong Hee Moon ${ }^{2}$, Sunghyun Kang ${ }^{1}$, Haryoung Poo ${ }^{2}$, Kwang-Hee Bae ${ }^{1, *}$ and Sang Chul Lee ${ }^{1, *}$ \\ Translational Research Center, ${ }^{2}$ Systemic Proteomics Research Center, KRIBB, Daejeon, 305-806, South Korea
}

Received 16 March 2007, Accepted 4 May 2007

\begin{abstract}
Eosinophils act as effectors in the inflammatory reactions of allergic diseases including atopic dermatitis. Atopic dermatitis patients and others with allergic disorders suffer from eosinophilia, an accumulation of eosinophils due to increased survival or decreased apoptosis of eosinophils. In this study, a differential phosphoproteome analysis of AML14.3D10 eosinophil cell line after treatment with IL-5 or dexamethasone was conducted in an effort to identify the phosphoproteins involved in the proliferation or apoptosis of eosinophils. Proteins were separated by 2-DE and alterations in phosphoproteins were then detected by Pro-Q Diamond staining. The significant quantitative changes were shown in nineteen phosphoproteins including retinoblastoma binding protein 7, MTHSP75, and lymphocyte cytosolic protein 1. In addition, seven phosphoproteins including galactokinase I, and proapolipoprotein, were appeared after treatment with IL-5 or dexamethasone. Especially, the phosphoAPOE protein was down-regulated in IL-5 treated AML14.3D10, while the more heavily phosphorylated APOE form was induced after dexamethasone treatment. These phosphoproteome data for the AML14.3D10 cell line may provide clues to understand the mechanism of eosinophilia as well as allergic disorders including atopic dermatitis.
\end{abstract}

Keywords: AML14.3D10, Atopic dermatitis, Eosinophilia, Phosphoproteome

"These authors contributed equally to this work.

*To whom correspondence should be addressed.

Tel: 82-42-860-4142; Fax: 82-42-860-4598

E-mail: lesach@kribb.re.kr and khbae@kribb.re.kr

\section{Introduction}

Atopic dermatitis (AD) is a chronic inflammatory skin disease that affects children (up to $20 \%$ ) and adult (1-3\%) worldwide. The manifestations of $\mathrm{AD}$ result from a complex interplay of susceptibility genes, environmental factors, pharmacological abnormalities, skin barrier defects, and immunological phenomena (Abramovits, 2005). AD skin lesions are characterized by increased IgE-bearing Langerhans cells, inflammatory dendritic cells, macrophages, eosinophils, and activated T lymphocytes. In particular, eosinophil numbers as well as eosinophil granule protein levels in peripheral blood are elevated in most AD patients and appear to correlate with disease activity (Trautmann et al., 2001; Simon et al., 2004). In addition to the increased production of eosinophils, inhibition of eosinophil apoptosis by IL-5 appears to play an important role at sites of allergic inflammation (Trautmann et al., 2000; Domae et al., 2003). In practice, purified blood eosinophils from $\mathrm{AD}$ patients that were cultured ex vivo had a reduced death kinetics compared with normal eosinophils. However, expression patterns of proteins associated with $\mathrm{AD}$ in eosinophils are not fully clarified (Kilty et al., 1999; Ogawa et al., 2004; Yoon et al., 2005; An et al., 2007).

Proteomic analysis involves using a combination of techniques, including two-dimensional electrophoresis (2$\mathrm{DE}$ ), image analysis, and mass spectrometry (MS). Proteins in a complex sample mixture can be separated by 2-DE to produce a high resolution 2-DE map in which stained proteins are visualized as spots of various sizes and intensities depending on the amount of protein in the sample. A computer-assisted comparison of the spot patterns in different 2-DE gels is then performed to assess changes in protein levels that are related to the disease or the process of interest. Differentially expressed protein spots selected and isolated from the 2-DE proteome maps can then be identified by mass spectrometry analysis. The proteomic approaches coupled with genomics have been applied to analyze many diseases and to probe for therapeutics (Park et al., 2004; Yoon et al., 
2005; Park et al., 2006). Among various post-translational modifications of proteins, phosphorylation is involved directly or indirectly in a variety of important cellular events (Raggiaschi et al., 2005; Kang et al., 2007). Thus, analysis of the entire phosphorylated proteins in a cell, so-called phosphoproteome, is an attractive subject.

The AML14.3D10 human myeloid leukemic cell line has been used as a standard cell line model for the study of eosinophil (Baumann and Paul, 1998). In this study, a phosphoproteomic analysis of the human eosinophil cell line AML14.3D10 was performed in an effort to identify the proteins involved in the survival or death of an eosinophil. Using phosphoprotein-specific dye after 2-DE of AML14.3D10 cell lysates treated with IL-5 (as a survival factor) or dexamethason (as a pro-apoptotic agent), several candidate phosphoproteins that are potentially involved in the survival or the death of eosinophils were identified.

\section{Materials and Methods}

Cell Lines, cell culture, and reagents. AML 14.3D10 was maintained in RPMI 1640 medium containing 10\% v/v FBS (Gibco) and 1\% v/v Antibiotic-Antimycotic (Gibco). It was then incubated for $24 \mathrm{~h}$. For the experiments, cells were incubated for $24 \mathrm{~h}$ in fresh medium, followed by treatment with IL-5 $(50 \mathrm{ng} / \mathrm{ml})$ or $10 \mu \mathrm{M}$ dexamethasone for $24 \mathrm{~h}$ at $37^{\circ} \mathrm{C}$ in a $5 \% \mathrm{CO}_{2}$ incubator.

IL-5 or dexamethasone treatment. Approximately $1 \times 10^{6}$ AML14.3D10 cells were resuspended in $20 \mathrm{ml}$ of fresh complete medium and incubated for $24 \mathrm{~h}$. They were then stimulated with IL5 (final $50 \mathrm{ng} / \mathrm{ml}$ ) or dexamethasone (final $10 \mu \mathrm{M}$ ) for $24 \mathrm{~h}$ at $37^{\circ} \mathrm{C}$ in a $5 \% \mathrm{CO}_{2}$ incubator. Following this, cells were collected by immediate centrifugation.

Sample preparation for 2-DE. AML14.3D10 cells were washed with PBS supplemented with $2 \mathrm{mM}$ sodium orthovanadate $\left(\mathrm{Na}_{3} \mathrm{VO}_{4}\right)$. The supernatant was removed and then resuspended with PBS. After being transferred into a new tube, it was centrifuged at $2,000 \mathrm{rpm}$ for $5 \mathrm{~min}$ and the supernatant was removed. Following this, the sample was resuspended with $200 \mu \mathrm{l}$ lysis buffer and sonicated two times followed by centrifuging at $13,000 \mathrm{~g}$ for $20 \mathrm{~min}$ at $4^{\circ} \mathrm{C}$. The supernatant was then removed. The protein concentration was determined by a Bradford assay. To precipitate the protein, four volumes of $100 \%$ acetone were added to the protein. It was stored at $-20^{\circ} \mathrm{C}$ for $2 \mathrm{~h}$ and then centrifuged at $13,000 \mathrm{~g}$ for $30 \mathrm{~min}$ at $4^{\circ} \mathrm{C}$, and the supernatant was removed. To remove the remaining salts, the pellet was washed for $10 \mathrm{~min}$ with $80 \%$ acetone and centrifuged at $13,000 \mathrm{~g}$ for $10 \mathrm{~min}$. It was then vacuum-dried and stored at $-80^{\circ} \mathrm{C}$. The resulting pellet was resuspended in a rehydration buffer [7 M urea, 4\% w/v CHAPS, $0.5 \% \mathrm{w} / \mathrm{v}$ IPG buffer ( $\mathrm{pH} 4-7 \mathrm{NL}), 2 \% \mathrm{w} / \mathrm{v}$ DTT and a trace of bromophenol blue].

2-DE. IEF was performed with an IPGphor ${ }^{\mathrm{TM}}$ unit (Amersham Biosciences, Uppsala, Sweden) using precast $18 \mathrm{~cm} \mathrm{pH} \mathrm{4-7} \mathrm{nonlinear}$ IPG gel strips (Amersham Biosciences). Equal amounts (1 mg) of total proteins were mixed with rehydration solution. IEF was then performed at $300 \mathrm{~V}$ for $1 \mathrm{~h}, 3,500 \mathrm{~V}$ for $1.5 \mathrm{~h}$ and 3,500 V for $18 \mathrm{~h}$. The current was limited to $20 \mathrm{~mA}$ per gel strip. After IEF separation, gel strips were equilibrated for $20 \mathrm{~min}$ in a reducing buffer of $65 \mathrm{mM}$ DTT, $6 \mathrm{M}$ urea, $2 \%$ SDS, and $30 \%$ glycerol in $1.5 \mathrm{M}$ Tris- $\mathrm{HCl}(\mathrm{pH} 8.8$ ), followed by another $20 \mathrm{~min}$ in an alkylating buffer of $135 \mathrm{mM}$ iodoacetamide, $6 \mathrm{M}$ urea, $2 \% \mathrm{SDS}$, and $30 \%$ glycerol in $1.5 \mathrm{M}$ Tris- $\mathrm{HCl}(\mathrm{pH} 8.8)$. The equilibrated strips were placed onto a SDS-PAGE apparatus and sealed with $0.5 \%$ agarose in a Laemmli running buffer. Discontinuous SDSPAGE was performed in a Protean 2D slab plate (Bio-Rad) using $12 \%$ polyacrylamide gels. Electrophoresis was performed at $16^{\circ} \mathrm{C}$ at a maximum current of $20 \mathrm{~mA}$ per gel.

Pro-Q staining. Fluorescent staining of 2-DE gels using Pro-Q Diamond phosphoprotein gel stain kit (Molecular Probes, Eugene, OR) was performed according to the manufacturer's guidelines. Briefly, the gels were fixed in 50\% methanol, $10 \%$ acetic acid overnight, washed with three changes of deionized water for 15 min per wash, followed by incubation in Pro-Q Diamond phosphoprotein gel stain for $180 \mathrm{~min}$. They were then destained with three changes of $20 \%$ acetonitrile in $5 \mathrm{mM}$ sodium acetate $\mathrm{pH}$ 4.0) for $1 \mathrm{~h}$. This was done three times. Useful images could be obtained at $3 \mathrm{~h}$ after staining, employing three successive destaining trials. Images were acquired using a Typhoon ${ }^{\mathrm{TM}} 9400$ imager (Amersham Biosciences) with an excitation of $532 \mathrm{~nm}$ and an emission of $580 \mathrm{~nm}$ to determine the phosphostain reacting proteins.

Image analysis. Gels were analyzed using Phoretix ${ }^{\mathrm{TM}}$ 2D Expression software (Nonlinear Dynamics) after being scanned using a transmissive flatbed scanner (UMAX) calibrated at an AGFA $25 \times 125 \mathrm{~mm}$ scale. The protein spot volume was evaluated based on the lowest boundary mode of background selection. The spot volumes were normalized based on the total spot volume for each gel. Protein spot intensity was defined as the normalized spot volume which is the ratio of the single spot volume to the total spots volumes on a 2-DE gel. The computer analysis allowed automatic detection and quantification of protein spots, as well as matching between control gels and gels from treated samples. The significance of differences of protein spots were evaluated by student's t-test, with $p<0.05$ taken as indicating significance.

Protein identification. Spots were excised as 1-2 $\mathrm{mm}^{2}$ slices, destained with freshly prepared $100 \mathrm{mM}$ ammonium bicarbonate (ABC) $/ 100 \%$ acetonitrile $(\mathrm{ACN}$ ) followed by $100 \% \mathrm{ACN}$ for $5 \mathrm{~min}$ two times and dried in a Speed Vac Plus SC110A (Savant, Holbrook) vacuum concentrator. The dried gel pieces were rehydrated with $20 \mathrm{ml}$ of $10 \mathrm{ng} / \mu \mathrm{l}$ trypsin solution, and digestion was allowed to continue at $37^{\circ} \mathrm{C}$ for $16 \mathrm{~h}$. The in-gel tryptic peptides were extracted with $70 \% \mathrm{ACN}$ and $0.1 \%$ trifluoroacetic acid (TFA) for $30 \mathrm{~min}$ three times. The extracted solutions were mixed and then dried in a vacuum concentrator. The resulting peptides were solubilized with $0.1 \% \mathrm{v} / \mathrm{v}$ TFA for MS analysis. Mass spectra were acquired via Axima CFR+ matrix assisted laser desorption/ionization time-of-flight mass spectrometry (MALDITOF-MS, Shimadzu Biotech, Japan). The obtained mass spectra were analyzed using a MASCOT PMF search (http://www.matrixscience.com). For protein identification, we performed database searching against 

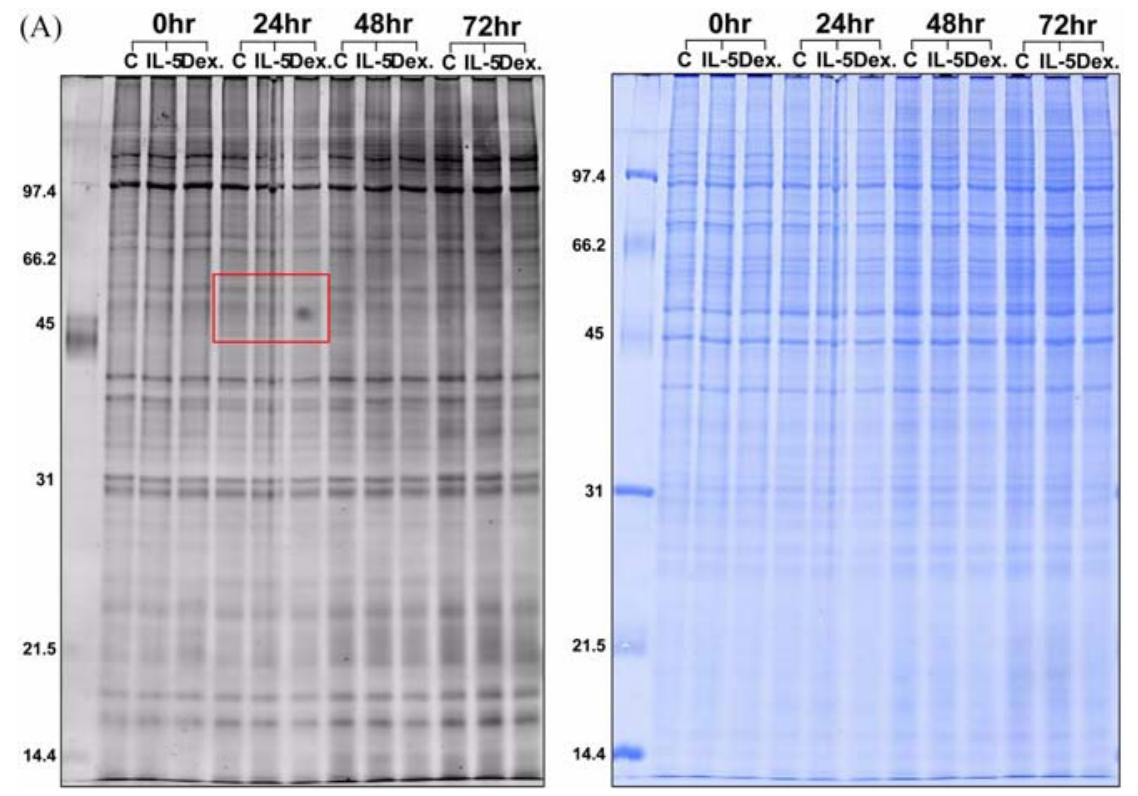

(B)

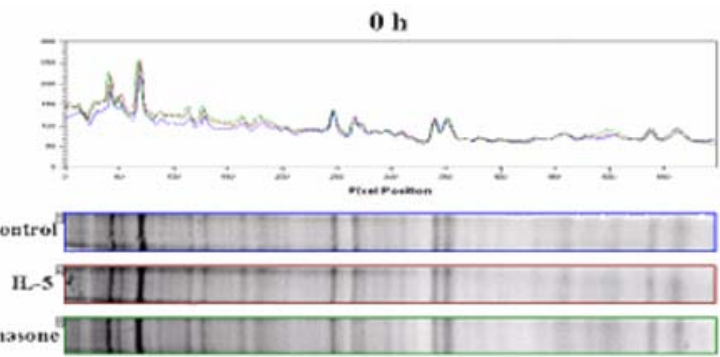

$48 \mathrm{~h}$
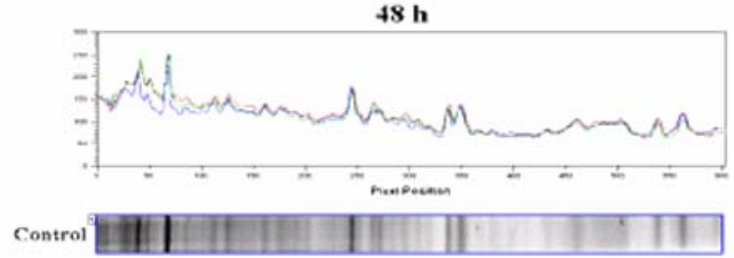

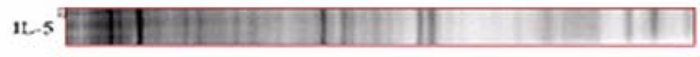
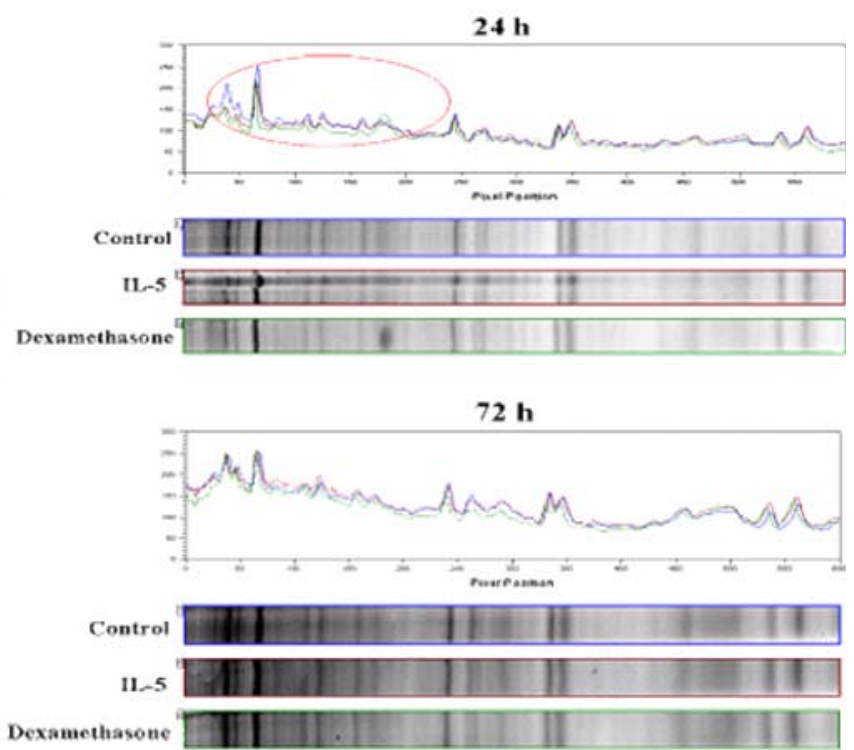

Fig. 1. Screening of the total phosphoproteins expression pattern after treatment with IL-5 or dexamethasone. (A) Time-course 1-DE images of phosphoproteins of eosinophils after treatment with IL-5 or dexamethasone. The total proteins were separated by $12 \%$ SDSPADE, and then stained with Pro-Q Diamond (left panel) and Coomassie Brilliant Blue (right panel). (B) Densitometric analysis of the expression pattern of the phosphoproteins. The regions showing slightly different expression pattern were indicated (by either box or circle).

the NCBInr database using the MASCOT program and the $\mathrm{p} I$ acquired from our image analysis. We used a protein molecular mass range of 6-200 $\mathrm{kDa}$ and a mass tolerance of $100 \mathrm{ppm}$ for the internal calibration. The proteins that failed by peptide mass finger printing were tried again by LC-MS/MS (Q-TOF Premier, Micromass).

\section{Results and Discussion}

Screening of total phosphoprotein expression pattern. To establish suitable conditions for the phosphoproteome change, the changes in the phosphoprotein expression pattern in AML14.3D10 eosinophil cell line induced by treatment with IL-5 or dexamethasone were investigated using 1-DE (Fig. 1A). The total phosphoproteins between the untreated control AML cell line and the IL-5 or dexamethasone treated AML cell line showed a similar expression pattern. Compared with the control, however, slight differences in the phosphoprotein expression pattern after the treatment with IL-5 or dexamethasone were detected at $24 \mathrm{~h}$ (Fig. 1B). Therefore, a proteome analysis of phosphoproteins treated with IL-5 or dexamethasone for $24 \mathrm{~h}$ was carried out. 
(A)

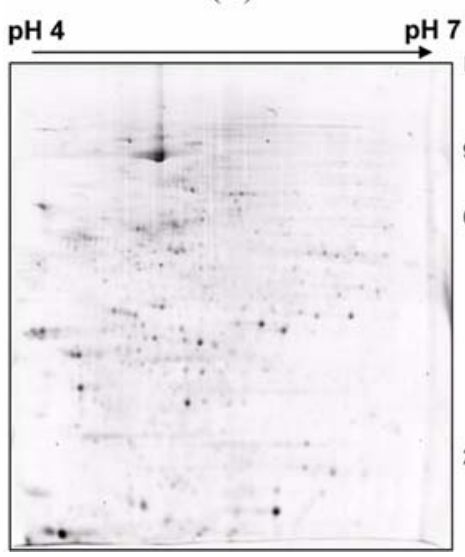

(B)

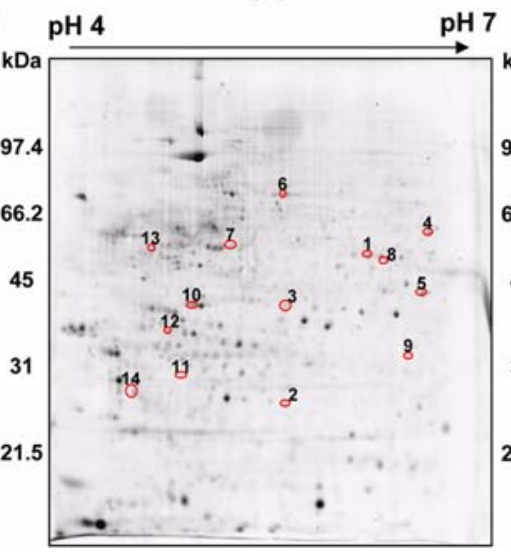

(C)

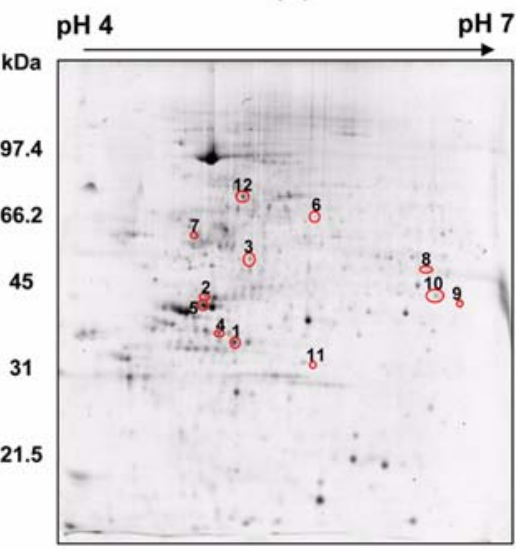

Fig. 2. Representative 2-DE gel images of IL-5 or dexamethasone treated AML14.3D10. The circles mark spots that show significant changes in expression levels. The indicated spot numbers in Table 1 and 2 correspond to the spots shown in Fig. 2. 2-DE was performed with $1 \mathrm{mg}$ of AML14.3D10 cell extract proteins after treatment with IL-5 (B) or dexamethasone (C), using pH 4-7NL immobilized $\mathrm{pH}$ gradients for IEF and $12 \%$ gels for SDS-PAGE.

\section{Phosphoproteome analysis of the AML14.3D10 cell line} after the IL-5 treatment. The proteins of AML14.3D10 cells after treatment with IL-5 or dexamethasone were separated by 2-DE. Alterations in phosphoproteins were then detected by Pro-Q Diamond staining. Among approximately 1,000 protein spots stained by coomassie brilliant blue, approximately 244 , 247, and 223 different phosphoprotein spots were detected in the untreated control, IL-5 treated, and dexamethasone treated samples, respectively. Protein spot changes greater than 1.5 fold in magnitude in three or more replicated gels were selected for protein identification. In the gels that were treated with IL-5 for $24 \mathrm{~h}$, a total of 14 reproducible protein changes were observed (Fig. 2 and 3, Table 1). Compared with the control, six phosphoproteins were up-regulated, five phosphoproteins were down-regulated, and three phosphoproteins were appeared when treated with IL-5.

A eukaryotic translation elongation factor $1 \gamma(\mathrm{eEF} 1 \gamma)$ was appeared in the IL-5 treated sample. The Ser-386 of eEF $1 \gamma$ is known to be phosphorylated. This site was identified at Cell Signaling Technology (CST) using PhosphoScan ${ }^{\circledR}$, CST's MS/ MS platform for phosphorylation site discovery. Sites were variously discovered in leukemia, lymphoma and carcinoma model cell lines and tumors. Additionally, it has been reported that eEF1 $\gamma$ was phosphorylated by cdc 2 kinase during meiotic maturation of Xenopus oocytes (Belle et al., 1990). However, it is unclear whether phospho-eEF1 $\gamma$ is involved in atopic dermatitis.

The phospho-mortalin (p-MTHSP75) spot was decreased after the IL-5 treatment. Mortalin is a chaperone protein associated with cell survival, stress response, intracellular trafficking, control of cell proliferation, mitochondrial biogenesis, and cell fate determination (Wadhwa et al., 2002). Mortalin is not induced by heat and is associated with cell aging and immortalization. It was known that mortalin is phosphorylated in a $\mathrm{Ca}^{2+}$-dependent manner. However, the exact role of
(A)
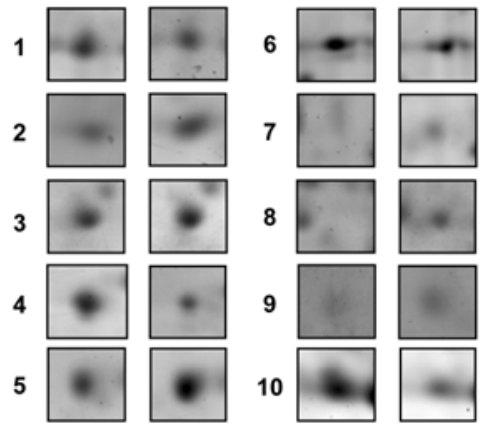

11
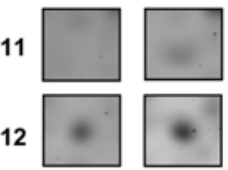

(B)
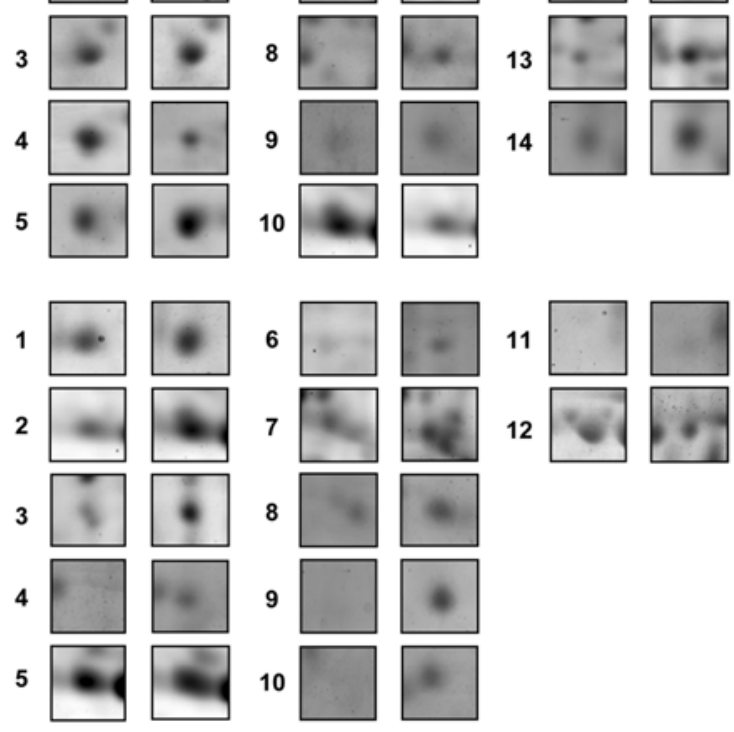

Fig. 3. Enlarged areas of silver stained $2 \mathrm{DE}$ gels of extracts from control and AML14.3D10 cells treated with IL-5 (A) or dexamethasone (B). 2-D gel images were analyzed with the phoretix $^{\mathrm{TM}} 2 \mathrm{D}$ Expression software (Nonlinear Dynamics). The indicated spot numbers correspond to the spots shown in Fig. 2.

phosphorylation in the cell is unclear (Osorio et al., 2006). Among the proteins interacting with mortalin, AIF and Apaf-1 have critical roles in apoptosis. Therefore, the phosphorylation of mortalin may be involved in proliferation/apoptosis of eosinophil.

The phosphatidylinositol transfer protein (PITP) family is a 
Table 1. Fourteen differentially expressed proteins in IL-5 treated AML14.3D10 cell line

\begin{tabular}{|c|c|c|c|c|c|c|c|c|c|}
\hline $\begin{array}{l}\text { Spot } \\
\text { No. }\end{array}$ & ID & $\begin{array}{l}\text { Seq. cov. } \\
(\%)\end{array}$ & $\begin{array}{l}\text { Matched } \\
\text { peptides }\end{array}$ & PI & $\begin{array}{l}\text { Mass } \\
(\mathrm{kDa})\end{array}$ & $\begin{array}{l}\text { Expectation } \\
\text { value }\end{array}$ & $\begin{array}{l}\text { Mascot } \\
\text { (score) }\end{array}$ & $\mathrm{NCBI}$ & $\begin{array}{l}\text { Fold } \\
\text { change }\end{array}$ \\
\hline 1 & angiotensinogen & 5 & 2 & 5.78 & 53407 & 0.00063 & 81 & gi|532198 & -2.1 \\
\hline 2 & $\begin{array}{l}\text { Chain C, Crystal Structure } \\
\text { Of Lipid-Free Human } \\
\text { Apolipoprotein A-I }\end{array}$ & 72 & 24 & 5.27 & 28061 & $1.2 \mathrm{E}-98$ & 998 & gi|90108666 & -1.9 \\
\hline 3 & apolipoprotein E & 41 & 13 & 5.81 & 36242 & $2.0 \mathrm{E}-66$ & 676 & gi|178853 & -2.0 \\
\hline 4 & hemopexin precursor & 4 & 2 & 6.57 & 52254 & 9.9E-06 & 99 & gi|386789 & +2.9 \\
\hline 5 & $\begin{array}{l}\text { translation initiation factor } \\
\text { eIF3 p40 subunit; eIF3p40 }\end{array}$ & 13 & 4 & 6.38 & 40075 & $9.9 \mathrm{E}-25$ & 259 & gi|3986482 & +1.9 \\
\hline 6 & MTHSP75 & 29 & 21 & 5.97 & 74019 & 3.9E-114 & 1152 & gi|292059 & -1.9 \\
\hline 7 & unnamed protein product & 18 & 8 & 5.63 & 48311 & $3.9 \mathrm{E}-22$ & 232 & gi|22761285 & Induction \\
\hline 8 & $\begin{array}{l}\text { Eukaryotic translation } \\
\text { elongation factor } 1 \gamma\end{array}$ & 6 & 3 & 6.25 & 50457 & 9.9E-04 & 79 & gi| 15530265 & Induction \\
\hline 9 & $\begin{array}{l}\text { PITPNB protein } \\
\text { [Homo sapiens] }\end{array}$ & 41 & 11 & 5.89 & 31903 & $3.1 \mathrm{E}-37$ & 384 & gi|21594294 & +1.6 \\
\hline 10 & $\begin{array}{l}\text { suppressor of G2 allele } \\
\text { of SKP1 }\end{array}$ & 17 & 5 & 5.11 & 38066 & $2.5 \mathrm{E}-13$ & 145 & gi|5730041 & -2.2 \\
\hline 11 & Proapolipoprotein & 8 & 2 & 5.45 & 28944 & 0.005 & 73 & gi|178775 & Induction \\
\hline 12 & RNA polymerase subunit & 40 & 8 & 4.74 & 31728 & $6.3 \mathrm{E}-38$ & 390 & gi|2920711 & +1.7 \\
\hline 13 & $\begin{array}{l}\text { hypothetical protein } \\
\text { LOC } 84306 \text { [Homo sapiens] }\end{array}$ & 5 & 2 & 4.71 & 40304 & 0.0013 & 79 & gi|14150141 & +1.9 \\
\hline 14 & $\begin{array}{l}\text { Chain B, 14-3-3 Protein } \\
\text { Theta (Human) } \\
\text { Complexed To Peptide }\end{array}$ & 28 & 11 & 5.17 & 29408 & 7.9E-45 & 460 & gi|71042777 & +2.2 \\
\hline
\end{tabular}

The values are the means from three independent determinations.

family of transfer proteins that can bind and exchange one molecule of phosphatidylinositol (PI) or phosphatidylcholine (PC) and facilitate the transfer of these lipids between different membrane compartments. In mammals, three soluble isoforms of PITP ( $a, b$ and $\mathrm{RdgBb}$ ) have been identified. PITPNB was originally purified as a sphingomyelin (SM) transfer protein using an assay that monitored the transfer of pyrenylacyl-labelled SM from donor to acceptor vesicles (Westermann et al., 1995). The ability to transfer SM was unique to PITPB. The Ser-261 of PITPNB is constitutively phosphorylated but has no effect on phospholipids transfer activity (Tiel et al., 2002). Thus far, the involvement of PITPNB in atopic dermatitis has not been reported. However, the data on PITPNB up-regulation after treatment with IL-5 suggest the possibility of an interconnection between regulation of SM metabolism and atopic dermatitis by phosphorylation of PITPNB.

Phosphoproteome analysis of the AML14.3D10 cell line after a dexamethasone treatment. When dexamethasone was treated as a pro-apoptotic agent, a total of 223 phosphoprotein spots were detected. Spots showing significant changed expression levels after treatment with dexamethasone compared with those from the control were are shown in Fig.
2. Among them, seven phosphoproteins were up-regulated, one phosphoprotein spot was down-regulated and four phosphoproteins were appeared (Fig. 3). The identified proteins showing differentially expressed patterns are listed in Table 2.

Lymphocyte cytosolic protein 1 (L-plastin), a malignant transformation-associated protein, is a member of family of actin filament cross-linkers. Fig. 4A showed matched peptide fragments and a representative MS/MS spectrum of L-plastin. In addition, MASCOT search results from MS/MS data suggest the possibility that Ser-5 of L-plastin might be phosphorylated although statistical significance is not achieved (since the ion score is low) (Fig. 4B). Recently, Friederich group reported the phosphorylation of Ser-5 in Lplastin (Janji et al., 2006). Ser-5 phosphorylation promotes its targeting to the actin cytoskeleton and increases its filament bundling activity in cells and in vitro (Wang and Brown, 1999). Phospho-L-plastin was decreased when dexamethasone was treated. However, it is unclear how phosphorylation of Lplastin is involved in atopic dermatitis.

Phospho-apolipoprotein E (p-APOE) was induced by dexamethasone, whereas decreased by IL-5 treatment. Thus, p-APOE can be used as an indicator for proliferation or apoptosis of eosinophils. APOE is known to mediate the 
Table 2. Twelve differentially expressed proteins in dexamethasone treated AML14.3D10 cell line

\begin{tabular}{|c|c|c|c|c|c|c|c|c|c|}
\hline $\begin{array}{l}\text { Spot } \\
\text { No. }\end{array}$ & ID & $\begin{array}{l}\text { Seq. cov. } \\
(\%)\end{array}$ & $\begin{array}{l}\text { Matched } \\
\text { peptides }\end{array}$ & PI & $\begin{array}{l}\text { Mass } \\
(\mathrm{kDa})\end{array}$ & $\begin{array}{l}\text { Expectation } \\
\text { value }\end{array}$ & $\begin{array}{r}\text { Mascot } \\
\text { (score) }\end{array}$ & NCBI & $\begin{array}{l}\text { Fold } \\
\text { change } e^{\dagger}\end{array}$ \\
\hline 1 & $\begin{array}{l}\text { Alternative splicing factor } \\
\text { (ASF) }\end{array}$ & 36 & 11 & 5.61 & 32321 & 0.0063 & 72 & gi|179073 & +2.9 \\
\hline 2 & $\begin{array}{l}\text { hypothetical protein } \\
\text { LOC } 345651\end{array}$ & 8 & 4 & 5.39 & 42318 & 7.9E-09 & 132 & gi|63055057 & +3.1 \\
\hline 3 & $\begin{array}{l}\text { placental protein } 17 \mathrm{~b} 1 ; \\
\text { PP17b1 }\end{array}$ & 22 & 9 & 5.37 & 47350 & $3.9 \mathrm{E}-49$ & 502 & gi|4206374 & +2.8 \\
\hline 4 & apolipoprotein E & 24 & 7 & 5.65 & 36302 & $6.3 \mathrm{E}-42$ & 430 & gi|178849 & Induction \\
\hline 5 & WD-40 repeat protein & 19 & 5 & 4.93 & 38814 & $1.5 \mathrm{E}-18$ & 196 & gi|4519417 & +1.7 \\
\hline 6 & $\begin{array}{l}\text { unnamed protein } \\
\text { product }\end{array}$ & 17 & 15 & 5.17 & 59720 & $3.9 \mathrm{E}-53$ & 543 & gi| 28317 & +2.4 \\
\hline 7 & $\begin{array}{l}\text { retinoblastoma } \\
\text { binding protein } 7\end{array}$ & 13 & 9 & 4.89 & 48132 & $6.2 \mathrm{E}-24$ & 250 & gi|4506439 & +1.8 \\
\hline 8 & $\begin{array}{l}26 \mathrm{~S} \text { proteasome } \\
\text { subunit } 9\end{array}$ & 14 & 5 & 6.08 & 47646 & $1.5 \mathrm{E}-05$ & 98 & gi|2150046 & +2.5 \\
\hline 9 & $\begin{array}{l}\text { Mitochondrial } \\
\text { ribosomal protein s22 }\end{array}$ & 33 & 12 & 7.7 & 41425 & $3.1 \mathrm{E}-38$ & 393 & gi|14424546 & Induction \\
\hline 10 & galactokinase 1 & 17 & 7 & 6.04 & 42702 & $3.9 \mathrm{E}-22$ & 232 & gi|4503895 & Induction \\
\hline 11 & $\begin{array}{l}\text { 60S acidic ribosomal protein } \\
\text { PO [Homo sapiens] }\end{array}$ & 41 & 13 & 7.68 & 27602 & $9.9 \mathrm{E}-34$ & 349 & gi|5815233 & Induction \\
\hline 12 & $\begin{array}{l}\text { lymphocyte cytosolic } \\
\text { protein } 1 \text { (L-plastin) } \\
\text { [Homo sapiens] }\end{array}$ & 57 & 38 & 5.29 & 70814 & $6.3 \mathrm{E}-154$ & 1522 & gi| 8217500 & -2.1 \\
\hline
\end{tabular}

The values are the means from three independent determinations.

binding, internalization, and catabolism of lipoprotein particles. There are three common APOE alleles of the APOE gene. The three APOE alleles differentially affect an individual's risk for developing Alzheimer's disease (Hoe et al., 2005; Raftery et al., 2005). Processes mediated by the APOE isoforms that may influence the progression of Alzheimer's disease include cholesterol transport and synapse formation, modification of neurite outgrowth and synaptic plasticity, destabilization of microtubules and $\beta$-amyloid clearance (Nathan et al., 2002; Beffert et al., 2004). Roles for APOE in repairing damage and promoting cell survival are also suggested by APOE up-regulation in conjunction with glial activation in neuronal injuries (Poirier et al., 1991). Recently, it was reported that there is nuclear and cytosolic pools of APOE in the human fibroblast. In particular, nuclear APOE protein levels were up-regulated during apoptosis. In addition, through in vivo studies using radio-labeling and immunoprecipitation, it was revealed that APOE could be phosphorylated (Quinn et al., 2004). In the present study, the induced APOE spot was detected at a more acidic position compared to that corresponding to its $\mathrm{p} I$ value on the 2-DE gel when dexamethasone was treated. This result suggests the possibility that a hyperphosphorylated nuclear APOE form is induced in response to apoptotic stimuli. Thus far, it is unclear how APOE affects atopic dermatitis. From the data in this study it is possible to postulate that phosphorylation of APOE may be involved in the survival or death of eosinophils and furthermore in the progression of atopic dermatitis.

Galactokinase is a major enzyme for galactose metabolism. Phosphogalactokinase I was appeared after the treatment with dexamethasone. Galactokinase was known to be up-regulated by hypoxia-inducible factor I (HIF-1) under hypoxia condition (Greijer et al., 2005). There is no report about involvement of galactokinase with atopic dermatitis, yet survival of cells under apoptotic conditions seems to be increased by upregulation of pathways leading to more energy. Therefore, galactokinase I is up-regulated by dexamethasone treatment to increase cellular energy level. However, it is unclear how phosphorylation of galactokinae I has influence on its enzymatic activity.

In conclusion, the phosphoproteomic analysis of AML14.3D10, the eosinophil model cell line, provides an understanding of the molecular mechanisms of eosinophilia as well as clues for biomarkers for the diagnosis of and new drug development for atopic dermatitis.

Acknowledgment This work was supported by the Molecular and Cellular BioDiscovery Research Program grant from the Ministry of Science and Technology, South Korea. 


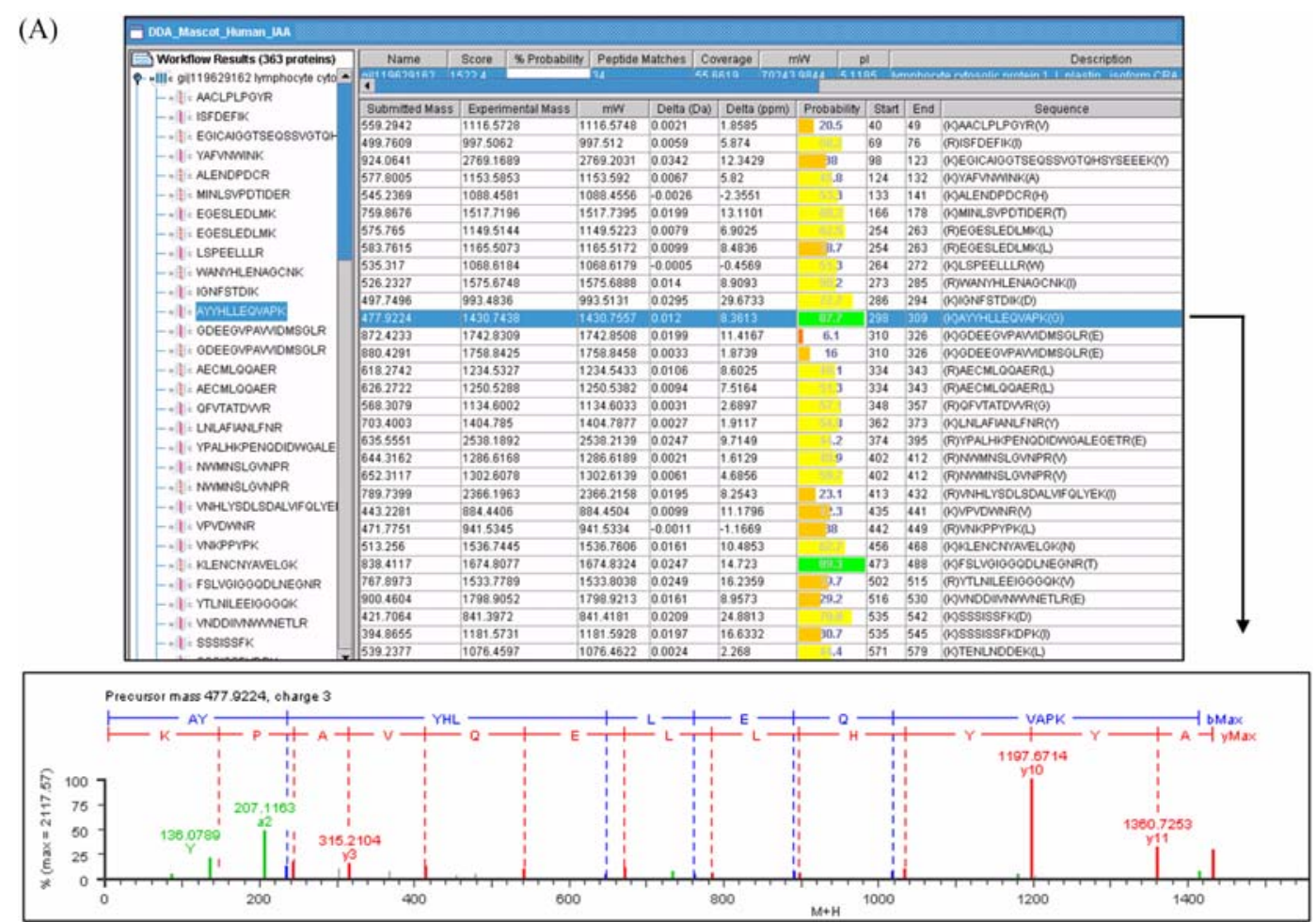

(B)

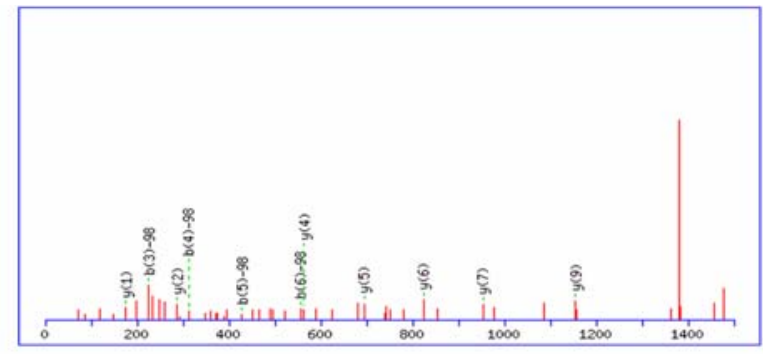

\begin{tabular}{|c|c|c|c|c|c|c|c|c|c|c|c|c|}
\hline \multicolumn{13}{|c|}{ 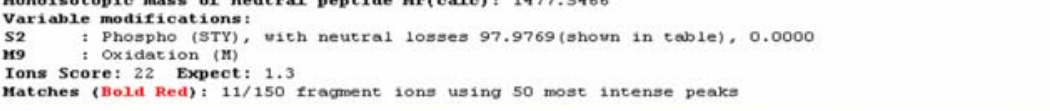 } \\
\hline$\#$ & b & $\mathbf{b}^{++}$ & $\mathbf{b}^{0}$ & $b^{0++}$ & Seq. & $y$ & $y^{++}$ & $y^{*}$ & $y^{n+t}$ & $y^{0}$ & $y^{0++}$ & $\#$ \\
\hline 1 & 58.0287 & 29.5180 & & & G & & & & & & & 12 \\
\hline 2 & 127.0502 & 64.0287 & 109.0396 & 55.0235 & $\mathrm{~s}$ & 1323.5555 & 662.2814 & 1306.5289 & 653.7681 & 1305.5449 & 653.2761 & 11 \\
\hline 3 & 226.1186 & 113.5629 & 208.1080 & 104.5577 & $\mathrm{v}$ & 1254.5340 & 627.7707 & 1237.5075 & 619.2574 & 1236.5235 & 618.7654 & 10 \\
\hline 4 & 313.1506 & 157.0790 & 295.1401 & 148.0737 & $\mathrm{~s}$ & 1155.4656 & 578.2365 & 1138.4391 & 569.7232 & 1137.4551 & 569.2312 & 9 \\
\hline 5 & 428.1776 & 214.5924 & 410.1670 & 205.5871 & D & 1068.4336 & 534.7204 & 1051.4071 & 526.2072 & 1050.4230 & 525.7152 & 8 \\
\hline 6 & 557.2202 & 279.1137 & 539.2096 & 270.1084 & E & 953.4067 & 477.2070 & 936.3801 & 468.6937 & 935.3961 & 468.2017 & 7 \\
\hline 7 & 686.2628 & 343.6350 & 668.2522 & 334.6297 & $\mathbf{E}$ & 824.3641 & 412.6857 & 807.3375 & 404.1724 & 806.3535 & 403.6804 & 6 \\
\hline 8 & 817.3032 & 409.1553 & 799.2927 & 400.1500 & M & 695.3215 & 348.1644 & 678.2949 & 339.6511 & 677.3109 & 339.1591 & 5 \\
\hline 9 & 964.3386 & 482.6730 & 946.3281 & 473.6677 & M & 564.2810 & 282.6441 & 547.2545 & 274.1309 & 546.2704 & 273.6389 & 4 \\
\hline 10 & 1093.3812 & 547.1942 & 1075.3707 & 538.1890 & E & 417.2456 & 209.1264 & 400.2191 & 200.6132 & 399.2350 & 200.1212 & 3 \\
\hline 11 & 1206.4653 & 603.7363 & 1188.4547 & 594.7310 & L & 288.2030 & 144.6051 & 271.1765 & 136.0919 & & & 2 \\
\hline 12 & & & & & $\mathbf{R}$ & 175.1190 & 88.0631 & 158.0924 & 79.5498 & & & 1 \\
\hline
\end{tabular}

Fig. 4. A representative LC-MS/MS spectrum and database query results. (A) Matched peptide fragment and error between experimental mass and theoretical mass. A representative spectrum of a peptide fragment ion is shown. (B) MS/MS spectrum of ${ }^{4}$ GSVSDEEMMELR ${ }^{15}$. The mascot search result suggests the possibility that Ser-5 of lymphocyte cytosolic protein (L-plastin) could be phosphorylated.

\section{References}

Abramovits, W. (2005) Atopic dermatitis. J. Am. Acad. Dermatol. 53, 86-93.
An, J. J., Kim, S. Y., Lee, S. H., Kim, D. W., Ryu, H. J., Yeo, S. I., Jang, S. H., Kwon, T. Y., Lee, S. C., Poo, H., Cho, S.-W., Lee, K. S., Park, J., Eom, W. S. and Choi, S. Y. (2007) Transduced PEP-1-Grb7 fusion protein suppressed LPS-induced 
COX-2 expression. J. Biochem. Mol. Biol. 40, 189-195.

Baumann, M. A. and Paul, C. C. (1998) The Aml14 and Aml14.3D10 cell lines: a long-overdue model for the study of eosinophils and more. Stem Cells 16, 16-24.

Beffert, U., Stolt, P. C. and Herz, J. (2005) Function of lipoprotein receptors in neurons. J. Lipid Res. 45, 403-409.

Belle, R., Cormier, P., Poulhe, R., Morales, J., Huchon, D. and Mulner-Lorillon, O. (1990) Protein phosphorylation during meiotic maturation of Xenopus oocytes: cdc2 protein kinase targets. Int. J. Dev. Biol. 34, 111-115.

Domae, M., Sagara, H., Sakaue, M., Fukuda, T. and Kamikawa, Y. (2003) The antiallergic drug oxatomide promotes human eosinophil apoptosis and suppresses IL-5-induced eosinophil survival. J. Allerg. Clin. Immunol. 111, 567-572.

Greijer, A. E., Groep, P., Kemming, D., Shvarts, A., Semenza, G. L., Meijer, G. A., Wiel, M. A., Belien, J. A. M., Diest, P. J. and Wall, E. (2005) Up-regulation of gene expression by hypoxia is mediated predominantly by hypoxia-inducible factor 1 (HIF-1). J. Pathol. 206, 291-304.

Hoe, H.-S., Harris, C. and Rebeck, G. W. (2005) Multiple pathways of apolipoprotein $\mathrm{E}$ signaling in primary neurons. $J$. Neurochem. 93, 145-155.

Janji, B., Giganti, A., Corte, V. D., Catillon, M., Bruyneel, E., Lentz, D., Plastino, J., Gettemans, J. and Friederich, E. (2006) Phosphorylation on Ser5 increases the F-actin binding activity and promotes its targeting to sites of actin assembly in cells. $J$. Cell Sci. 119, 1947-1960.

Kang, T. H., Bae, K.-H., Yu, M.-J., Kim, W. K., Hwang, H. R., Jung, H., Lee, P. Y., Kang, S., Yoon, T.-S., Park, S. G., Ryu, S. E. and Lee, S. C. (2007) Phosphoproteomic analysis of neuronal cell death by glutamate-induced oxidative stress. Proteomics in press.

Kilty, I. C. and Vickers, P. J. (1999) Studies of differential gene expression in clinically derived eosinophil populations. Clin. Exp. Aller. 29, 1671-1680.

Li, H.-C., Guan, L.-S. and Wang, Z.-Y. (2003) Overexpression of RbAp46 facilitates stress-induced apoptosis and suppresses tumorigenicity of neoplastigenic breast epithelial cells. Int. J. Cancer 105, 762-768.

Loyola, A. and Almouzni, G. (2004) Histone chaperones, a supporting role in the limelight. Biochem. Biophys. Acta 1677, 3-11.

Nathan, B. P., Jiang, Y., Wong, G. K., Shen, F., Brewer, G. J. and Struble, R. G. (2002) Apolipoprotein E4 inhibits, and apolipoprotein E3 promotes neurite outgrowth in cultured adult mouse cortical neurons through the low-density lipoprotein receptor-related protein. Brain Res. 928, 96-105.

Ogawa, K., Itoh, M., Miyagawa, M., Nagasu, T., Sugita, Y., Katsunuma, T., Akasawa, A., Matsumoto, K., Tsujimoto, G., Saito, H. and Hashida, R. (2004) Expression of a human SOCS protein, HSOCP-1, in peripheral blood eosinophils from patients with atopic dermatitis. Int. Arch. Aller. Immunol. 134 (suppl. 1), 2-6.

Osorio, C., Sullivan, P. M., He, D. N., Mace, B. E., Ervin, J. F., Strittmatter, W. J. and Alazte, O. (2006) Mortalin is regulated by $A P O E$ in hippocampus of $\mathrm{AD}$ patients and by human APOE in TR mice. Neurobiol. Ageing doi:10.1016/ j.neurobiolaging.2006.08.011

Park, Y.-D., Kim, S.-y., Jang, H.-S., Seo, E.-Y., Namkung, J.-H., Park, H.-S., Cho, S. Y., Paik, Y.-K. and Yang, J.-M. (2004) Towards a proteomic analysis of atopic dermatitis: A twodimensional-polyacrylamide gel electrophoresis/mass spectrometric analysis of cultured patient-derived fibroblast. Proteomics 4, 3446-3455.

Park, Y.-D., Jang, H.-S., Kim, S.-y., Ko, S.-K., lyou, Y.-J., Lee, D.-Y., Paik, Y.-K. and Yang, J.-M. (2006) Two-dimensional electrophoretic profiling of atopic dermatitis in primary cultured keratinocytes from patients. Proteomics 6, 1362-1370.

Poirier, J., Hess, M., May, P. C. and Finch, C. E. (1991) Astrocytic apolipoprotein E mRNA and GFAP mRNA in hippocampus after entorhinal cortex lesioning. Brain Res. Mol. Brain Res. 11, 97-106.

Quinn, C. M., Kagedal, K., Terman, A., Stroikin, U., Brunk, U. and Jessup, W. (2004) Induction of fibroblast apolipoprotein E expression during apoptosis, starvation-induced growth arrest and mitosis. Biochem. J. 378, 753-761.

Raftery, M., Campbell, R., G., Glaros, E., Tye, K.-A., Halliday, G. M., Jessup, W. and Garner, B. (2005) Phosphorylation of apolipoprotein $\mathrm{E}$ at an atypical protein kinase CK2 PSD/E site in vitro. Biochemistry 44, 7346-7353.

Raggiaschi, R., Gotta, S. and Terstappen, G. C. (2005) Phosphoproteome analysis. Biosci. Rep. 25, 33-44.

Simon, D., Braathen, L. R. and Simon, H.-U. (2004) Eosinophils and atopic dermatitis. Allergy 59, 561-570.

Tiel, C. M., Westerman, J., Paasma, M. A., Hoebens, M. M., Wirtz, K. W. A. and Snoek, G. T. (2002) The golgi localization of phosphatidylinositol transfer protein $\mathrm{b}$ requires the protein kinase C-dependent phosphorylation of serine 262 and is essential for maintaining plasma membrane sphingomyelin levels. J. Biol. Chem. 277, 22447-22452.

Trautmann, A., Akdis, M., Blaser, K. and Akdis, C. A. (2000) Role of dysregulated apoptosis in atopic dermatitis. Apoptosis 5, 425-429.

Trautmann, A., Akdis, M., Klunker, S., Blaser, K. and Akdis, C. A. (2001) Role of apoptosis in atopic dermatitis. Int. Arch. Aller. Immunol. 124, 230-232.

Wadhwa, R., Taira, K. and Kaul, S. C. (2002) An Hsp70 family chaperone, mortalin/mthsp70/Grp75: what, when, and where? Cell Stress Chaperones 7, 309-316.

Wang, J. and Brown, E. J. (1999) Immune complex-induced integrin activation and L-plastin phosphorylation require protein kinase A. J. Biol. Chem. 274, 24349-24356.

Westerman, J., De Vries, K. J., Somerharju, P., TimmermansHerejgers, J. L., Snoek, G. T. and Wirtz, K. W. (1995) A sphingomyelin-transferring protein from chicken liver. Use of pyrene-labeled phospholipid. J. Biol. Chem. 270, 14263-14266.

Yoon, S. W., Kim, T. Y., Sung, M. H., Kim, C. J. and Poo, H. (2005) Comparative proteomic analysis of peripheral blood eosinophils from healthy donors and atopic dermatitis patients with eosinophilia. Proteomics 5, 1987-1995. 